\title{
Pemanasan Fisik Menurunkan Kejadian Kram Otot Triceps Surae pada Atlet Renang
}

\section{Physical Heating Reduces Genesis of Triceps Surae Muscle Cramps in Swimming Athletes}

Firza Yoga Baskoro 1 , Sigit Moerjono ${ }^{2}$, Hema Dewi Anggraheny ${ }^{3}$

1) dv Mahasiswa Program Studi Pendidikan Dokter Fakultas Kedokteran Universitas Muhammadiyah Semarang

2) Bagian Ilmu Kedokteran Olah Raga, Fakultas Kedokteran Universitas Muhammadiyah Semarang

3) Bagian Ilmu Kesehatan Masyarakat, Fakultas Kedokteran Universitas Muhammadiyah Semarang

Fakultas Kedokteran Universitas Muhammadiyah Semarang. Jl. Wonodri Sendang Raya 2A, Semarang. Email: Firzabaskoro@gmail.com

\begin{abstract}
Abstrak
Latar Belakang : Olah raga renang melibatkan sebagian besar anggota gerak. Berenang tanpa persiapan sebelumnya dapat mengakibatkan kram otot. Pemanasan fisik yang kurang optimal dan gaya berenang merupakan risiko dari kram otot.. Penelitian ini bertujuan menganalisis hubungan pemanasan fisik awal dan gaya berenang terhadap kejadian kram otot pada atlet renang di Semarang.

Metode : Penelitian ini merupakan studi observasional analitik dengan pendekatan cross sectional yang di analisis dengan uji chi square. Sampel adalah atlet renang di Semarang, yang berjumlah 42 orang. Teknik pengambilan sampel menggunakan total sampling. Waktu pelaksanaan bulan September - Oktober 2016. .

Hasil : Terdapat hubungan antara pemanasan fisik dengan kram otot triceps surae ( $\phi$ value $=0,012$ $; O R=0,190,95 \% C I 0,05-0,72)$. Tidak terdapat hubungan antara gaya berenang dengan kram otot triceps surae $(\mathrm{p}$ value $=0,429)$.
\end{abstract}

Simpulan : Pemanasan fisik berperan dalam mencegah kram otot triceps surae pada olah raga renang

Kata kunci : pemanasan fisik, gaya berenang, kram otot triceps surae

\begin{abstract}
Background: Swimming sport involves most members of the motion. Swimming without prior preparation can lead to muscle cramps. Less optimal physical heating and swimming style is a risk of muscle cramps. This study aims to analyze the relationship of physical warming and the style of swimming to the occurrence of muscle cramps in swimming athletes in Semarang.
\end{abstract}

Method: This was an analytic observational study with cross sectional approach which was analyzed by chi square test. The sample is a swimming athlete in Semarang, which amounts to 42 people. The sampling technique uses total sampling. The execution time of September - October 2016..

Results: There was a relationship between physical heating with triceps surae muscle cramps ( $\mathrm{p}$ value $=$ 0.012; $\mathrm{OR}=0.190,95 \% \mathrm{CI} 0.05-0.72$ ). There was no association between swimming forces with triceps surae muscle cramps ( $\mathrm{p}$ value $=0.429)$.

Conclusion: Physical heating plays a role in preventing triceps surae muscle cramps in swimming sport

Keywords: warm up, swimming stroke, muscle cramps of triceps surae 


\section{PENDAHULUAN}

Renang bisa dilakukan semua kalangan umur baik itu anak-anak,remaja,dewasa dan orang tua. ${ }^{1}$ Renang menjadi salah satu dari berbagai macam olahraga yang paling digemari di Indonesia. Berenang memerlukan koordinasi dari sebagian besar anggota gerak ekstremitas atas dan bawah. Namun olahraga renang juga dapat menyebabkan kram otot, apabila tidak dilakukan secara benar. Kram otot dapat terjadi dikarenakan berbagai faktor seperti intensitas latihan berlebih, pemanasan fisik yang tidak optimal atau bisa dikarenakan resiko dari gaya berenang. ${ }^{2}$

Kram otot adalah kontraksi yang dialami oleh sekelompok otot secara terus menerus sehingga menyebabkan timbulnya rasa nyeri. ${ }^{3}$ Kram otot merupakan kondisi yang sering dialami oleh atlet renang terutama kram otot triceps surae. ${ }^{3}$ Triceps surae terdiri atas m.gastrocnemius, $m$ soleus, dan $m$. plantaris yang berperan dalam semua gerakan pada extremitas inferior seperti berjalan, melompat, berlari dan berperan penting pada pergerakan kaki saat berenang.

Banyak masyarakat yang belum mengetahui pentingya pemanasan fisik sebelum olahraga untuk mencegah terjadinya cedera. Pemanasan fisik merupakan suatu langkah untuk pencegahan cedera. Pemanasan fisik yang optimal baik dari durasi dan jenis gerakan, dapat meningkatkan penyesuain jaringan lunak sebelum melakukan olahraga.

Faktor lain yang dapat meningkatkan resiko cedera adalah gaya berenang. Gaya berenang merupakan gaya atau gerakan koordinasi antara lengan dan tungkai yang bergerak secara bersama sehingga seseorang akan bergerak maju ketika didalam air. ${ }^{4}$ Gaya berenang yang salah dapat menyebabkan cedera pada atlet renang. Penerapan gaya bebas dapat meningkatkan resiko cedera bahu. ${ }^{4}$

\section{METODE PENELITIAN}

Waktu penelitian dilaksanakan pada Oktober - November 2016. Ruang lingkup penelitian pada Atlet Lari di Kota Semarang. Jenis penelitian ini merupakan analisis observasional dengan pendekatan cross sectional, yaitu suatu rancangan studi yang melakukan identifikasi, pengukuran variabel, dan mencari hubungan antar variabel untuk menerangkan kejadian yang diamati berdasarkan data yang sudah tersedia. Cara pengambilan sampel pada penelitian ini menggunakan total sampling. Dengan besar populasi 53 atlet dan jumlah sampel sejumlah 42 atlet. Sampel dalam penelitian ini adalah seluruh anggota populasi yakni Seluruh atlet renang di tim Semarang yang bersedia menjadi responden. Uji analisis menggunakan uji Chi Square.

\section{HASIL}

Penelitian telah dilakukan pada Oktober - November 2016. Hasil penelitian dapat diketahui bahwa dari 42 atlet renang, sebagian besar responden melakukan pemanasan fisik yang sesuai $(54,85 \%)$ atlet renang. Sebagian besar sampel menggunakan gaya bebas (61,9\%). Sebagian besar sampel mengalami kram otot triceps surae $(54,8 \%)$. 
Tabel 1 : Hubungan antara Pemanasan fisik dengan Kram otot triceps surae

\begin{tabular}{|c|c|c|c|c|c|c|c|c|c|}
\hline \multirow{3}{*}{\multicolumn{2}{|c|}{ Analisis Bivariat }} & \multicolumn{4}{|c|}{$\begin{array}{l}\text { Kram otot } \\
\text { triceps surae }\end{array}$} & \multirow{2}{*}{\multicolumn{2}{|c|}{ Jumlah }} & \multirow{3}{*}{$\begin{array}{l}\text { Nilai } \\
\text { p }\end{array}$} & \multirow{3}{*}{$\begin{array}{c}\text { OR } \\
(\mathrm{CI} 95 \%)\end{array}$} \\
\hline & & \multicolumn{2}{|c|}{$\mathrm{Ya}$} & \multicolumn{2}{|c|}{ Tidak } & & & & \\
\hline & & $\mathrm{n}$ & $(\%)$ & $\mathrm{n}$ & $(\%)$ & $\mathrm{n}$ & $(\%)$ & & \\
\hline \multirow{2}{*}{$\begin{array}{c}\text { Pemanasan } \\
\text { fisik }\end{array}$} & Sesuai & 8 & 36,4 & 14 & 63,6 & 22 & 100 & \multirow{3}{*}{0,012} & \multirow{3}{*}{$\begin{array}{c}0,190 \\
(0,050-0,723)\end{array}$} \\
\hline & $\begin{array}{l}\text { Tidak } \\
\text { Sesuai }\end{array}$ & 15 & 75 & 5 & 25 & 20 & 100 & & \\
\hline \multicolumn{2}{|c|}{ Jumlah } & 23 & 54,8 & 19 & 45,2 & 42 & 100 & & \\
\hline
\end{tabular}

Hasil uji statistik menunjukkan nilai signifikansi sebesar 0,012, dengan nilai Odds Ratio sebesar 0,190 (CI 95; 0,050 - 0,723) . Terdapat hubungan antara pemanasan fisik dengan kram otot triceps surae, serta dengan nilai

Tabel 2 : Hubungan antara Gaya berenang dengan Kram otot triceps surae

\begin{tabular}{|c|c|c|c|c|c|c|c|c|c|}
\hline \multirow{3}{*}{\multicolumn{2}{|c|}{ Analisis Bivariat }} & \multicolumn{4}{|c|}{$\begin{array}{l}\text { Kram otot } \\
\text { triceps surae }\end{array}$} & \multirow{2}{*}{\multicolumn{2}{|c|}{ Jumlah }} & \multirow{3}{*}{$\begin{array}{l}\text { Nilai } \\
\text { p }\end{array}$} & \multirow{3}{*}{$\begin{array}{c}\text { OR } \\
(\text { CI } 95 \%)\end{array}$} \\
\hline & & \multicolumn{2}{|c|}{$\mathrm{Ya}$} & \multicolumn{2}{|c|}{ Tidak } & & & & \\
\hline & & $\mathrm{n}$ & $(\%)$ & $\mathrm{n}$ & $(\%)$ & $\mathrm{n}$ & $(\%)$ & & \\
\hline \multirow{2}{*}{$\begin{array}{c}\text { Gaya } \\
\text { berenang }\end{array}$} & $\begin{array}{l}\text { Gaya } \\
\text { Bebas }\end{array}$ & 13 & 50 & 13 & 50 & 26 & 100 & \multirow{3}{*}{0,429} & 0,600 \\
\hline & $\begin{array}{c}\text { Non Gaya } \\
\text { bebas }\end{array}$ & 10 & 62,5 & 6 & 37,5 & 16 & 100 & & $\begin{array}{c}(0,168- \\
2,139)\end{array}$ \\
\hline \multicolumn{2}{|c|}{ Jumlah } & 23 & 54,8 & 19 & 45,2 & 42 & 100 & & \\
\hline
\end{tabular}

Hasil uji statistik menunjukkan nilai signifikansi sebesar 0,429, dengan nilai Odds Ratio sebesar 0,600 (CI 95\%; 0,168 - 2,139). Tidak terdapat hubungan antara gaya berenang dengan kram otot triceps surae. Ratio sebesar 0,600 (CI $95 \% ; 0,168-2139)$ odds ratio sebesar 0,190 (CI 95; 0,050 - 0,723), dapat diartikan bahwa pemanasan fisik mampu menjadi faktor penurun risiko terjadinya kram otot triceps surae.

\section{PEMBAHASAN}

Hasil penelitian menunjukkan bahwa terdapat hubungan antara Pemanasan fisik dengan Kram otot triceps surae. dengan nilai prevalensi sebesar 0,012 $(<0,05)$. Pemanasan fisik yang tidak optimal dan gaya berenang dapat menjadi penyebab terjadinya kram otot. ${ }^{5}$ Kram otot dapat terjadi karena sirkulasi darah dan fleksibiltas otot yang kurang saat melakukan 
olahraga, sehingga otot tidak mampu menerima pembebanan. Sirkulasi darah dan fleksibiltas yang tidak optimal dapat dikarenakan pemanasan fisik yang belum sesuai. Sirkulasi darah yang tidak optimal akan menyebabkan defisit energi, Ketika seorang atlet menggunakan gaya berenang dibutuhkan energi untuk melawan tahanan di permukaan air sehingga ketika sirkulasi darah kurang optimal akan menyebabkan terganggunya metabolisme otot yang dapat menyebabkan penimbunan asam laktat yang menyebabkan terjadinya kram otot. ${ }^{6}$

Pemanasan yang dilakukan sebelum aktifitas olahraga sesungguhnya berguna untuk menyiapkan sistem kardiovaskuler. Sistem kardiovaskuler berperan dalam pengangkutan oksigen dan nutrisi menuju otot guna pembentukan energi. ${ }^{7}$ Hal tersebut terjadi karena pada saat pemanasan metabolisme otot meningkat dan menyebabkan vasodilatasi intramuscular sehingga akan meningkatkan sirkulasi darah menuju ke otot. Selain itu pemanasan juga dapat meningkatkan suhu tubuh. ${ }^{8}$ Suhu tubuh yang meningkat akan menyebabkan fleksibiltas otot juga meningkat, sehingga otot akan optimal dalam menjalankan fungsi relaksasi dan kontraksi. ${ }^{8}$

Hasil penelitian menunjukkan bahwa tidak terdapat hubungan antara gaya berenang dengan kram otot triceps surae dengan nilai prevalensi sebesar 0,429 $(>0,05)$. Hal tersebut dimungkinkan karena posisi dan teknik gaya berenang yang digunakan sesuai secara teori, selain itu teknik pengambilan data yang hanya berupa wawancara juga mempengaruhi hasil sehingga tidak ada hubungan gaya berenang dengan kejadian kram otot triceps surae. Kemungkinan gaya berenang akan dapat menyebabkan cedera oleh karena dipengaruhi faktor yang lain seperti belum melakukan pemanasan fisik awal yang optimal, belum memiliki fleksibilitas otot yang cukup dan intensitas latihan yang berlebihan. ${ }^{2}$

Gaya berenang dapat menjadi salah satu faktor yang dapat meningkatkan resiko terjadinya cedera pada atlet renang. Teknik, fleksibilitas dan adaptasi tubuh merupakan komponen penting dalam penerapan gaya berenang. Penerapan teknik gaya berenang yang salah dapat meningkatkan resiko cedera. Fleksibilitas dibutuhkan untuk menunjang ROM dan adaptasi tubuh yang cukup dapat membantu atlet dalam proses penyiapan energi yang dibutuhkan untuk melakukan gaya berenang. Energi penting dibutuhkan untuk melawan tahanan di dalam air saat melakukan gaya berenang. ${ }^{9}$ Bila proses produksi energi terhambat oleh karena adaptasi tubuh yang kurang, akan menyebabkan peningkatan produksi asam laktat oleh tubuh sehingga meningkatkan resiko terjadinya kram otot.

Energi yang dibutuhkan pada renang gaya dada lebih besar dibandingkan dengan renang gaya bebas. Pada gaya bebas arah gerakannya sejajar dengan sumbu tubuh dan tidak ada gerakan sendi panggul atau lengan ke arah lateral seperti gerakan pada renang gaya dada. ${ }^{9}$ Arah gerakan yang sejajar dengan sumbu tubuh dan tidak ada gerakan sendi panggul atau lengan ke arah lateral sangat penting untuk meminimalkan hambatan di dalam air, karena air mengalir di sekitar tubuh dalam arah yang sejajar. Arah gerakan yang sejajar dengan sumbu tubuh juga berfungsi untuk meneruskan kecepatan yang dihasilkan oleh kayuhan lengan dan dorongan kaki. ${ }^{9}$ Oleh karena itu kebutuhan 
energi yang dibutuhkan pada gaya bebas lebih kecil dari gaya berenang yang lain sehingga kebutuhan oksigenpun juga lebih sedikit dibutuhkan pada gaya bebas. Hal tersebut dapat diartikan bahwa kemungkinan terjadinya metabolisme otot secara anaerob yang menghasilkan asam laktat pada gaya bebas lebih sedikit terjadi.

\section{SIMPULAN DAN SARAN}

Berdasarkan hasil penelitian seperti yang telah dijelaskan pada bab sebelumnya, dapat disimpulkan bahwa pemanasan fisik awal dapat menurunksn kejadian kram otot triceps surae.

Saran untuk metode pengambilan data menggunakan teknik observasi langsung.

\section{DAFTAR PUSTAKA}

1. Badruzaman. Modul Teori Tenang 1. Bandung: FPOK, Universitas Pendidikan Indonesia. 2007.

2. Cole C. Heart Rate Recovery Immediately After Exercise as a Predictor of Mortality. New England Journal Medicine 341(18) : 13511357. 1999.
3. Supriyanto A. Cedera bahu (Swimmer's Shoulders) pada Perenang Penanganan dan rehabilitasinya. Yogyakarta : FIK UNY. 2007.

4. James N. Swimming Biomechanics and Injury Prevention. Jurnal The Physician and Sport Medicine. Vol 31. No. 1. 41-46.2003

5. Parkkari JU, Kujala M. "Is it Possible to Prevent Sports Injuries?: Review of Controlled Clinical Trials and Recommendations for Future Work." Sports Medicine 31(14): 985-995. 2001

6. Guyton AC dan Hall JE. Buku Ajar Fisiologi Kedokteran hal 112-114 . Edisi 11. Jakarta: EGC.2008.

7. Michael A. Sciene of Flexibility Third Edition. 2004

8. Michael A. 300 Teknik Peregangan Olahraga. Jakarta. PT. Raja Grafindo Persada. 2003

9. Barbosa T, Bragada M, Reis V, Marinho D, Carvalho C And Silva A. Energetics and Biomechanics as Determining Factors of Swimming Performance, Updating the State of Art. Journal of Science and Medicine in Sport 13: pp 262-265. 2010. 